\title{
The Attitude towards Vaccination of Health Sciences Students at a Spanish University Improved over the First 18 Months of the COVID-19 Pandemic
}

\author{
Francisco Javier Pérez-Rivas ${ }^{1,2, *(\mathbb{D})}$, Ramón Del Gallego-Lastra ${ }^{1,3} \mathbb{E}^{\mathbb{D}}$, Cristina Maria Alves Marques-Vieira ${ }^{4}(\mathbb{D}$, \\ Candelas López-López ${ }^{1,2,5,6} \mathbb{C D}^{\text {, Silvia Domínguez-Fernández }}{ }^{2,7} \mathbb{( D}$, Milagros Rico-Blázquez ${ }^{1,2,8}$ (D) \\ and María Julia Ajejas Bazán 1,2,9
}

1 Departamento de Enfermería, Facultad de Enfermería, Fisioterapia y Podología, Universidad Complutense de Madrid, Plaza Ramón y Cajal no. 3, Ciudad Universitaria, 28040 Madrid, Spain; rgallego@ucm.es (R.D.G.-L.); canlopez@ucm.es (C.L.-L.); milarico@ucm.es (M.R.-B.); majejas@ucm.es (M.J.A.B.)

2 Grupo de Investigación UCM "Salud Pública-Estilos de Vida, Metodología Enfermera y Cuidados en el Entorno Comunitario", Departamento de Enfermería, Facultad de Enfermería, Fisioterapia y Podología, Universidad Complutense de Madrid, 28040 Madrid, Spain; sildom01@ucm.es

3 Grupo de Investigación UCM “Humanidades, Ciencia y Salud”, Departamento de Enfermería, Facultad de Enfermería, Fisioterapia y Podología, Universidad Complutense de Madrid, 28035 Madrid, Spain

4 Center Interdisciplinary Research in Health (CIIS), Nursing School (Lisbon), Institute of Health Sciences, Universidade Católica Portuguesa, 1649-023 Lisbon, Portugal; cristina_marques@ucp.pt

check for updates

Citation: Pérez-Rivas, F.J.; Gallego-Lastra, R.D.; Marques-Vieira, C.M.A.; López-López, C.;

Domínguez-Fernández, S.;

Rico-Blázquez, M.; Ajejas Bazán, M.J. The Attitude towards Vaccination of Health Sciences Students at a Spanish University Improved over the First 18 Months of the COVID-19 Pandemic. Vaccines 2022, 10, 237. https:// doi.org/10.3390/vaccines10020237

Academic Editors: Tiziana Ramaci and Massimiliano Barattucci

Received: 23 December 2021

Accepted: 1 February 2022

Published: 3 February 2022

Publisher's Note: MDPI stays neutral with regard to jurisdictional claims in published maps and institutional affiliations.

Copyright: (C) 2022 by the authors. Licensee MDPI, Basel, Switzerland. This article is an open access article distributed under the terms and conditions of the Creative Commons Attribution (CC BY) license (https:// creativecommons.org/licenses/by/ $4.0 /)$.
5 Grupo de Investigación en Cuidados (InveCuid), Instituto de Investigación Sanitaria Hospital 12 de Octubre (imas12), 28041 Madrid, Spain

6 Department of Intensive Care, Hospital Universitario 12 de Octubre, 28041 Madrid, Spain

7 Centro Municipal de Salud Comunitaria Centro, Madrid Salud, Ayuntamiento de Madrid, 28013 Madrid, Spain

8 Unidad de Investigación de la Gerencia Asistencial de Atención Primaria, Servicio Madrileño de la Salud, 28035 Madrid, Spain

9 Academia Central de la Defensa, Escuela Militar de Sanidad, Ministerio de Defensa, 28040 Madrid, Spain

* Correspondence: frjperez@ucm.es

Abstract: It is important to know the attitudes of students of health sciences (SHSs) towards vaccination since they will be tomorrow's health professionals. Vaccination is a powerful tool in the fight against COVID-19. The aim of the present, cross-sectional study was to examine how the COVID-19 pandemic has influenced the attitude of SHSs towards vaccination. Data were collected in the form of a questionnaire from all students of nursing, physiotherapy and chiropody matriculated at a Madrid University for the academic year 2019/2020 (i.e., before the start of the pandemic [Q1]), and from all those matriculated for the year 2021/22 (i.e., c18 months after the pandemic was declared [Q2]). A multivariate analysis was performed to identify the influence of sex, degree being studied, course year and the time of answering (Q1 or Q2), on the dimensions Beliefs, Behaviours and General Attitude. Overall, 1894 questionnaires were returned (934 [49.3\%] for Q1, and 960 [50.7\%] for Q2), of which $70.5 \%$ were completed by students of nursing, $14 \%$ by students of physiotherapy and $15.4 \%$ by those studying chiropody. In Q2, the results for all three dimensions were significantly better $(p<0.05)$. The most important influencing factors were being a student of nursing, being in the final years of training (years 3 or 4), female gender and answering at the time of Q2. The results obtained are encouraging since student nurses (who showed Q1 and Q2 General Attitude scores of 3.34 and 3.47 (maximum possible 4 ), respectively $[p<0.05]$ ) are the health professionals of tomorrow most likely to be involved in vaccination programmes.

Keywords: attitudes; beliefs; health occupations; COVID-19; students; vaccination 


\section{Introduction}

Despite vaccination being among the most successful means of controlling transmissible diseases [1], recent years have seen the rise of anti-vaccination movements, the rhetoric of which has contributed towards vaccine hesitancy $[2,3]$ —even among health professionals $[4,5]$. This is particularly worrying, since the latter have a great influence on the patients they see [6,7]. Indeed, it is well known that the beliefs and attitudes of health professionals influence the behaviour of, and decisions taken by, their patients (and their respective families) with regard to vaccination [8-10]. Students of the health sciences (SHSs) will be tomorrow's health professionals, and on their shoulders will lie the responsibility of carrying out future vaccination programmes. Knowing their attitudes towards vaccination is, therefore, important; this might help in the task of allaying their fears and concerns.

A number of international studies have shown that attitudes can vary considerably depending on where, when and how they are examined. For example, reports from Serbia [11], Florida (USA) [12], Australia [13] and central and southern Italy [14] highlight more positive attitudes than others from the USA [15], Germany [16], Canada [17] and Italy (Messina) [18]. In January 2020, our group examined the general attitude of students of nursing, physiotherapy and chiropody (all at the Universidad Complutense de Madrid, Madrid, Spain) towards vaccination [19], and found attitudes to be generally positive, especially among students of nursing, female students and students in their final years.

The vaccination programme to combat the COVID-19 pandemic, which began to affect Europe in the first quarter of 2020 [20], has been the subject of controversy, with the media, politicians and the general public taking very different positions [21]. Although the papers being published on the safety and effectiveness of the vaccines used have reduced hesitancy in some groups [22], there has also been an "infodemic" with messages designed to misinform and confuse the public [23]. Google Trends data reveal anti-vaccine searches to have risen continuously in number over the course of the pandemic [24], and anti-vaxxers and COVID-deniers have had a notable presence in the media [25]. The aim of the present cross-sectional study was to compare the attitudes of SHSs at a Spanish university towards vaccination before and during the pandemic (18 months in).

\section{Materials and Methods}

The study subjects were 3222 students of nursing, physiotherapy and chiropody at the Universidad Complutense de Madrid (Madrid, Spain), 1582 of whom were matricu-lated for the academic year 2019/2020 (i.e., before the pandemic was declared), and 1640 of whom were matriculated for the year 2021/2022 (i.e., which began c18 months after the pandemic was declared). All matriculated students, irrespective of their course year, were asked to complete the "Attitudes and Behaviour with Regard To Vaccination Among Health Science Students Questionnaire" (ACVECS according to its Spanish initials-Cuestionario sobre Actitudes y Conductas hacia la Vacunación entre Estudiantes de Ciencias de la Salud) [26]) between 15-30 January 2020 (Q1), and 1 October to 22 November 2021 (Q2). Thus, all students completed at least one questionnaire, and some completed both Q1 and Q2. The ACVECS questionnaire is composed of 24 items, the first 15 of which examine the dimension "Beliefs", and the last nine "Behaviour". Taken together, these 24 items determine the "General Attitude" towards vaccination $[19,26]$. In the validation analysis performed by the questionnaire's authors, ordinal $\alpha$ (a rating of reliability) was 0.92 , the Kaiser-Meyer-Olkin index was 0.90, and the Barlet sphericity value was $\chi 2=4142.1(p<0.001)$. The answer provided for each item is recorded on a five-point Likert scale from $0=$ totally disagree, to 4 = totally agree (items 1, 2, 7, 8, 15 and 23 have inverted scoring) [19,26]. Beliefs, Behaviour and General Attitude scores of $\geq 3$ were considered positive (i.e., vaccination favourable), $\leq 1$ negative and 2 neutral or indifferent.

Data were collected during visits to classrooms. The students were told the purpose of the study and that their anonymity was assured. Those students who wished to take part did so over a period of 10-15 min of classroom time using the Google Forms online platform. Sample size requirement analysis showed that 310 respondents were needed 
for a $5 \%$ error and $95 \%$ confidence limits, as discussed in previous studies [19]. The data collected were then transferred to a Microsoft Excel $365^{\circledR}$ database.

Means and standard deviation were calculated for quantitative variables, and frequencies and percentages for qualitative variables. Student's $t$-test was used to compare quantitative variables, and the chi-squared test to compare qualitative variables. The effect of gender, age, degree being studied, course year (1,2,3 or 4) and the time of answering (Q1 or Q2) on Beliefs, Behaviour and General Attitude were examined by multiple linear regression (forward stepwise, with an F probability value of $\leq 0.05$ for entry and $>0.10$ for exit). Significance was set at $p \leq 0.05$. All calculations were performed using SPSS ${ }^{\circledR}$ v.25.0 software.

The study was approved by the Research Committee of the Faculty of Nursing, Physiotherapy and Chiropody, Universidad Complutense de Madrid, and by the Ethics in Research Committee of the Hospital Universitario Clínico San Carlos (CI: 20/376-E).

\section{Results}

Of the 3222 students matriculated over the two academic years, 1894 (58.8\%) completed the questionnaire, i.e., $934(49.3 \%)$ at Q1, and $960(50.7 \%)$ at Q2. Some $70.5 \%$ of the returned questionnaires were provided by students of nursing, $14 \%$ by students of physiotherapy and $15.6 \%$ by those studying chiropody. Taking into account the number of students studying each of these degrees, the participation by students of nursing was somewhat higher $(64.8 \%$, compared with $47.3 \%$ for students of physiotherapy, and $48.9 \%$ for those studying chiropody). Participation was slightly lower among students studying their final years (Table 1). Women made up $80.9 \%$ of all respondents $(85.3 \%$ of nursing students were female, as were $80.1 \%$ of chiropody students and $59.8 \%$ of physiotherapy students; $p<0.001$ ). The mean age of respondents was $21.4 \pm 0.26$ years (range $17-60$ years). The students of chiropody were a little older (22.0 \pm 0.59 years) than those studying nursing (21.5 \pm 0.33 years) or physiotherapy $(20.6 \pm 0.53$ years $)(p=0.011)$.

Table 1. Participation in terms of degree being pursued and course year (Q1, Q2 and Total).

\begin{tabular}{|c|c|c|c|c|c|c|c|}
\hline \multirow{3}{*}{ Survey } & \multirow{3}{*}{ Degree } & \multirow{2}{*}{ Total Matriculated } & \multirow{2}{*}{ Total Participating Subjects } & \multicolumn{4}{|c|}{ Participating Subjects by Course Year } \\
\hline & & & & $\mathbf{1}^{\circ}$ & $2^{\circ}$ & $3^{\circ}$ & $4^{\circ}$ \\
\hline & & n (\%) & n (\%) & n (\%) & n (\%) & n (\%) & n (\%) \\
\hline \multirow{4}{*}{$\begin{array}{c}\mathrm{Q} 1 \\
(\operatorname{Jan} / 2020)\end{array}$} & Nursing & 1039 (65.6) & $624(66.9)$ & $220(35.2)$ & $192(30.8)$ & $120(19.3)$ & 92 (14.7) \\
\hline & Physiotherapy & 262 (16.6) & $162(17.3)$ & $40(24.6)$ & $50(30.8)$ & $30(18.5)$ & 42 (25.9) \\
\hline & Chiropody & $281(17.8)$ & $148(15.8)$ & 32 (21.6) & $58(39.2)$ & 28 (18.9) & $30(20.3)$ \\
\hline & Total & $1582(100.0)$ & 934 (100.0) & $292(31.2)$ & $300(32.1)$ & $178(19.2)$ & $164(17.5)$ \\
\hline \multirow{4}{*}{$\begin{array}{c}\text { Q2 } \\
\text { (OCT/NOV } \\
2021)\end{array}$} & Nursing & $1024(62.4)$ & $712(74.2)$ & $171(24.0)$ & $150(21.1)$ & $194(27.2)$ & $197(27.7)$ \\
\hline & Physiotherapy & $300(18.3)$ & $104(10.8)$ & $42(40.4)$ & $29(27.9)$ & $18(17.3)$ & $15(14.4)$ \\
\hline & Chiropody & $316(19.3)$ & $144(15.0)$ & $42(29.2)$ & $30(20.8)$ & $41(28.5)$ & $31(21.5)$ \\
\hline & Total & $1640(100.0)$ & $960(100.0)$ & $255(26.6)$ & $209(21.8)$ & $253(26.4)$ & $243(25.3)$ \\
\hline \multirow{4}{*}{$\begin{array}{l}\text { TOTAL } \\
\text { (Q1/Q2) }\end{array}$} & Nursing & $2063(64.0)$ & 1336 (70.5) & $391(29.3)$ & $342(25.6)$ & 314 (23.5) & 289 (21.6) \\
\hline & Physiotherapy & 562 (17.4) & $266(14.0)$ & $82(30.8)$ & 79 (29.7) & $48(18.0)$ & 57 (21.4) \\
\hline & Chiropody & 597 (18.5) & $292(15.4)$ & $74(25.0)$ & 88 (29.7) & $69(23.3)$ & $61(20.6)$ \\
\hline & Total & $3222(100.0)$ & $1894(100.0)$ & $547(28.9)$ & $509(26.9)$ & $431(22.8)$ & $407(21.5)$ \\
\hline
\end{tabular}

For Q2, the results for the three dimensions measured by the AVECS questionnaire, i.e., Beliefs, Behaviours and General Attitude, were all significantly better $(p<0.05)$ than those recorded for Q1 (Table 2).

Table 2. Distribution of scores for the ACVECS questionnaire dimensions (Q1 and Q2).

\begin{tabular}{|c|c|c|c|c|c|c|}
\hline Survey & $\begin{array}{c}\text { Beliefs } \\
\text { Mean } \pm \text { SD }\end{array}$ & $p$ Value & $\begin{array}{c}\text { Behaviour } \\
\text { Mean } \pm \text { SD }\end{array}$ & $p$ Value & General Attitude Mean \pm SD & $p$ Value \\
\hline $\begin{array}{c}\text { Q1(ENE/2020) } \\
\text { Q2 (OCT_NOV/2021) }\end{array}$ & $\begin{array}{l}3.23 \pm 0.47 \\
3.38 \pm 0.45\end{array}$ & 0.001 & $\begin{array}{l}3.35 \pm 0.51 \\
3.47 \pm 0.47\end{array}$ & 0.009 & $\begin{array}{l}3.27 \pm 0.46 \\
3.41 \pm 0.43\end{array}$ & 0.006 \\
\hline
\end{tabular}

Tables 3-5 show the change in scores between Q1 and Q2 for all three dimensions measured, with respect to gender, degree being studied and course year. Compared with 
the Q1 scores, the Q2 scores for students of nursing showed significant improvements in all dimensions $(p<0.05)$. Furthermore, taking students of all three degrees together, Q2 improvements were seen for both men and women, and for students in their first and third years $(p<0.05)$. Q2 improvements were, in fact, seen across the board for students of all degrees, although not always so clearly in each of the dimensions measured. No Q2 scores were poorer than Q1 scores.

Table 3. Distribution of Q1 and Q2 scores for the Beliefs dimension of the ACVECS questionnaire with respect to gender, degree being studied, and course year for each degree and as a whole for all degrees taken together.

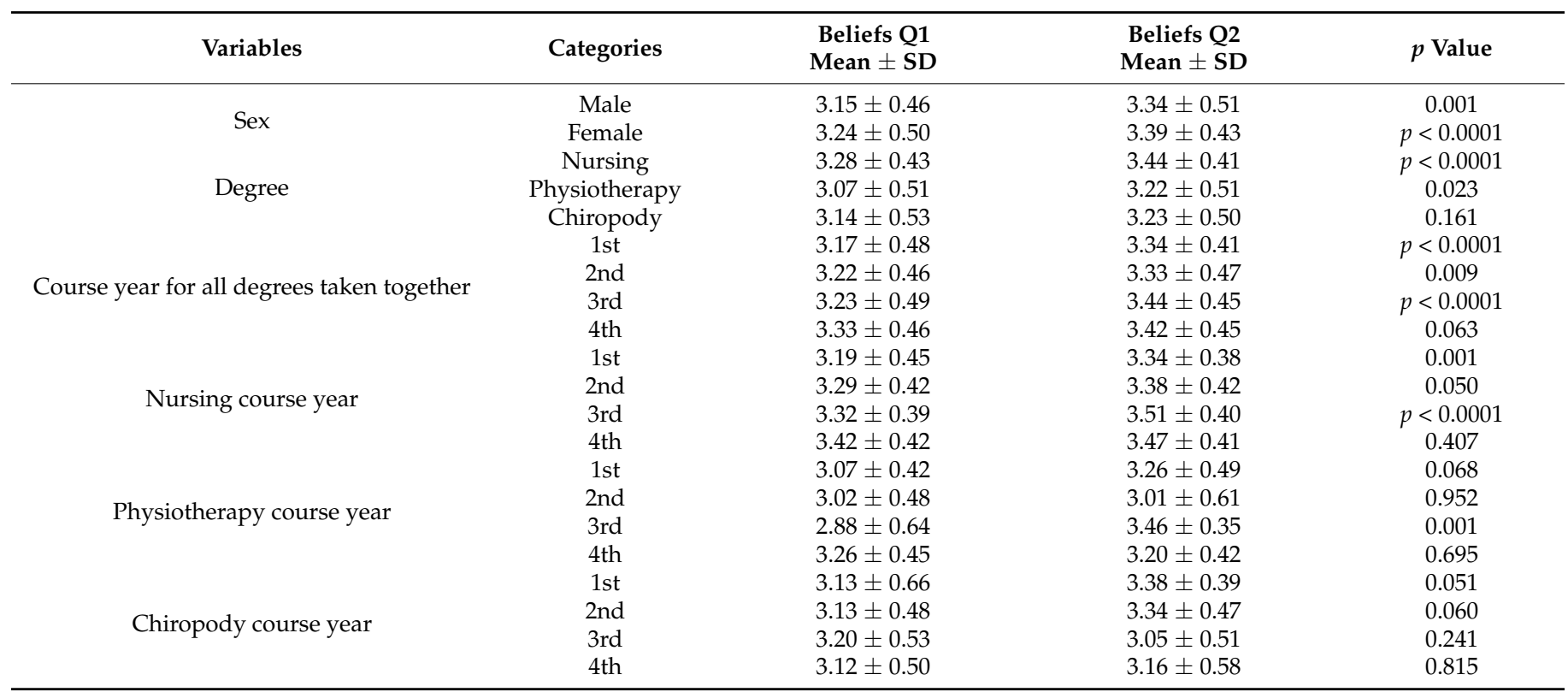

Table 4. Distribution of Q1 and Q2 scores for the Behaviour dimension of the ACVECS questionnaire with respect to gender, degree being studied, and course year for each degree and as a whole for all degrees taken together.

\begin{tabular}{|c|c|c|c|c|}
\hline Variables & Categories & Behaviour $Q$ Mean \pm SD & $\begin{array}{c}\text { Behaviour } Q^{2} \\
\text { Mean } \pm S D\end{array}$ & $p$ Value \\
\hline \multirow{2}{*}{ Sex } & Male & $3.25 \pm 0.53$ & $3.36 \pm 0.54$ & 0.040 \\
\hline & Female & $3.38 \pm 0.50$ & $3.49 \pm 0.45$ & $p<0.0001$ \\
\hline \multirow{3}{*}{ Degree } & Nursing & $3.42 \pm 0.45$ & $3.52 \pm 0.44$ & $p<0.0001$ \\
\hline & Physiotherapy & $3.16 \pm 0.62$ & $3.30 \pm 0.54$ & 0.061 \\
\hline & Chiropody & $3.29 \pm 0.57$ & $3.36 \pm 0.53$ & 0.264 \\
\hline \multirow{4}{*}{ Course year for all degrees taken together } & 1 st & $3.38 \pm 0.50$ & $3.46 \pm 0.44$ & 0.049 \\
\hline & 2nd & $3.34 \pm 0.51$ & $3.41 \pm 0.52$ & 0.134 \\
\hline & $3 \mathrm{rd}$ & $3.29 \pm 0.58$ & $3.49 \pm 0.47$ & $p<0.0001$ \\
\hline & 4 th & $3.39 \pm 0.47$ & $3.50 \pm 0.47$ & 0.026 \\
\hline \multirow{3}{*}{ Nursing course year } & 1st & $3.40 \pm 0.46$ & $3.48 \pm 0.43$ & 0.125 \\
\hline & 2nd & $3.43 \pm 0.43$ & $3.48 \pm 0.48$ & 0.370 \\
\hline & $3 \mathrm{rd}$ & $3.35 \pm 0.48$ & $3.55 \pm 0.43$ & $p<0.0001$ \\
\hline \multirow{5}{*}{ Physiotherapy course year } & 4 th & $3.50 \pm 0.41$ & $3.55 \pm 0.42$ & 0.407 \\
\hline & 1 st & $3.25 \pm 0.59$ & $3.43 \pm 0.50$ & 0.164 \\
\hline & $2 \mathrm{nd}$ & $3.10 \pm 0.60$ & $3.05 \pm 0.61$ & 0.698 \\
\hline & $3 \mathrm{rd}$ & $3.02 \pm 0.79$ & $3.49 \pm 0.43$ & 0.029 \\
\hline & 4 th & $3.23 \pm 0.48$ & $3.20 \pm 0.46$ & 0.836 \\
\hline \multirow{4}{*}{ Chiropody course year } & $1 \mathrm{st}$ & $3.38 \pm 0.60$ & $3.44 \pm 0.38$ & 0.601 \\
\hline & 2 nd & $3.25 \pm 0.55$ & $3.44 \pm 0.50$ & 0.122 \\
\hline & $3 \mathrm{rd}$ & $3.26 \pm 0.63$ & $3.23 \pm 0.54$ & 0.826 \\
\hline & 4 th & $3.29 \pm 0.50$ & $3.35 \pm 0.70$ & 0.692 \\
\hline
\end{tabular}


Table 5. Distribution of Q1 and Q2 scores for the General Attitude dimension of the ACVECS questionnaire with respect to gender, current degree, and course year for each degree and as a whole for all degrees taken together.

\begin{tabular}{|c|c|c|c|c|}
\hline Variables & Categories & $\begin{array}{c}\text { General Attitude Q1 } \\
\text { Mean } \pm \text { SD }\end{array}$ & $\begin{array}{l}\text { General Attitude Q2 } \\
\text { Mean } \pm \text { SD }\end{array}$ & $p$ Value \\
\hline \multirow{2}{*}{ Sex } & Male & $3.19 \pm 0.49$ & $3.35 \pm 0.50$ & 0.003 \\
\hline & Female & $3.30 \pm 0.45$ & $3.43 \pm 0.41$ & $p<0.0001$ \\
\hline \multirow{3}{*}{ Degree } & Nursing & $3.34 \pm 0.41$ & $3.47 \pm 0.39$ & $p<0.0001$ \\
\hline & Physiotherapy & $3.11 \pm 0.52$ & $3.25 \pm 0.50$ & 0.026 \\
\hline & Chiropody & $3.20 \pm 0.52$ & $3.28 \pm 0.49$ & 0.176 \\
\hline \multirow{4}{*}{$\begin{array}{c}\text { Course year for all degrees } \\
\text { taken together }\end{array}$} & 1 st & $3.25 \pm 0.46$ & $3.38 \pm 0.39$ & $p<0.0001$ \\
\hline & 2nd & $3.26 \pm 0.44$ & $3.36 \pm 0.47$ & 0.021 \\
\hline & $3 \mathrm{rd}$ & $3.25 \pm 0.49$ & $3.46 \pm 0.43$ & $p<0.0001$ \\
\hline & 4 th & $3.35 \pm 0.43$ & $3.45 \pm 0.44$ & 0.035 \\
\hline \multirow{4}{*}{ Nursing course year } & 1st & $3.27 \pm 0.43$ & $3.39 \pm 0.37$ & 0.005 \\
\hline & 2nd & $3.34 \pm 0.38$ & $3.42 \pm 0.42$ & 0.096 \\
\hline & $3 \mathrm{rd}$ & $3.33 \pm 0.39$ & $3.53 \pm 0.38$ & $p<0.0001$ \\
\hline & 4 th & $3.45 \pm 0.39$ & $3.50 \pm 0.39$ & 0.379 \\
\hline \multirow{4}{*}{ Physiotherapy course year } & 1 st & $3.14 \pm 0.46$ & $3.32 \pm 0.48$ & 0.085 \\
\hline & 2nd & $3.05 \pm 0.49$ & $3.03 \pm 0.58$ & 0.837 \\
\hline & $3 \mathrm{rd}$ & $2.94 \pm 0.66$ & $3.47 \pm 0.33$ & 0.003 \\
\hline & 4 th & $3.25 \pm 0.43$ & $3.21 \pm 0.42$ & 0.735 \\
\hline \multirow{4}{*}{ Chiropody course year } & 1 st & $3.22 \pm 0.62$ & $3.40 \pm 0.36$ & 0.130 \\
\hline & 2nd & $3.17 \pm 0.48$ & $3.38 \pm 0.45$ & 0.067 \\
\hline & $3 r d$ & $3.22 \pm 0.55$ & $3.12 \pm 0.51$ & 0.413 \\
\hline & 4 th & $3.18 \pm 0.45$ & $3.23 \pm 0.60$ & 0.752 \\
\hline
\end{tabular}

Taking the students of all three degrees together, the Q2 scores for 16 of the $24(66.7 \%)$ questionnaire items (nos. 2, 3, 6, 7, 8, 9, 10, 11, 13, 14, 15, 16, 20, 22, 23, 24 in Table 6) were significantly higher than the corresponding Q1 scores. Five (nos. 1, 5, 17, 19, 21) of the remaining eight items also showed higher Q2 scores, but the differences were not significant due to the already high corresponding Q1 scores. No significant difference was seen between the Q1 and Q2 scores for the remaining three items (nos. 4, 12, 18) (Table 6).

Table 6. Frequencies and percentages of students showing positive and negative scores on the 24 items of the ACVECS questionnaire.

\begin{tabular}{|c|c|c|c|c|c|}
\hline Questionnaire Items & SURVEY & $\begin{array}{l}\text { Disagree } \\
\text { n }(\%)\end{array}$ & $\begin{array}{l}\text { ND/NA } \\
\text { n (\%) }\end{array}$ & $\begin{array}{l}\text { Agreed } \\
\text { n (\%) }\end{array}$ & $p$ Value \\
\hline \multirow{2}{*}{ 1. I have doubts about the effectiveness of vaccines } & Q1 & $750(80.3)$ & $80(8.6)$ & $104(11.1)$ & \multirow[b]{2}{*}{0.261} \\
\hline & $\hat{\mathrm{Q} 2}$ & $797(83.0)$ & $76(7.9)$ & $87(9.1)$ & \\
\hline \multirow{2}{*}{ 2. I would rather have influenza than be vaccinated against it } & $\hat{\mathrm{Q}} 1$ & $703(75.3)$ & $135(14.5)$ & $96(10.3)$ & \multirow{2}{*}{$p<0.001$} \\
\hline & Q2 & $814(84.8)$ & $90(9.4)$ & $56(5.8)$ & \\
\hline \multirow{2}{*}{ 3. I am convinced that marketed vaccines are safe } & Q1 & $73(7.8)$ & $151(16.2)$ & $710(76.0)$ & \multirow{2}{*}{$p<0.001$} \\
\hline & Q2 & $49(5.1)$ & $100(10.4)$ & $811(84.5)$ & \\
\hline \multirow{2}{*}{ 4. I am interested in learning more about vaccination } & $\hat{\mathrm{Q}} 1$ & $71(7.6)$ & $198(21.2)$ & $665(71.2)$ & \multirow{2}{*}{0.693} \\
\hline & Q2 & $66(6.9)$ & $216(22.5)$ & $678(70.6)$ & \\
\hline \multirow{2}{*}{$\begin{array}{l}\text { 5. I believe it important to check my vaccination status before } \\
\text { travelling to a tropical country such as Mexico or Thailand }\end{array}$} & Q1 & $7(0.7)$ & $23(2.5)$ & $904(96.8)$ & \multirow{2}{*}{0.192} \\
\hline & Q2 & $9(0.9)$ & $13(1.4)$ & $938(97.7)$ & \\
\hline \multirow{2}{*}{ 6. National and international vaccine campaigns are cost-effective } & Q1 & $146(15.6)$ & $300(32.1)$ & $488(52.2)$ & \multirow{2}{*}{$p<0.001$} \\
\hline & Q2 & $120(12.5)$ & $221(23.0)$ & $619(64.5)$ & \\
\hline \multirow{2}{*}{$\begin{array}{l}\text { 7. It is not worth being vaccinated against a disease for which } \\
\text { effective treatment exists }\end{array}$} & Q1 & $786(84.2)$ & $92(9.9)$ & $56(6.0)$ & \multirow{2}{*}{$p<0.001$} \\
\hline & Q2 & $868(90.4)$ & $66(6.9)$ & $26(2.7)$ & \\
\hline \multirow{2}{*}{ 8. Vaccinating the adult population is not important } & Q1 & $882(94.4)$ & $22(2.4)$ & $30(3.2)$ & \multirow{2}{*}{0.001} \\
\hline & Q2 & $939(97.8)$ & $7(0.7)$ & $14(1.5)$ & \\
\hline \multirow{2}{*}{$\begin{array}{l}\text { 9. Health science students are ethically obliged to be vaccinated } \\
\text { against influenza }\end{array}$} & Q1 & $146(15.6)$ & $217(23.2)$ & $571(61.1)$ & \multirow[b]{2}{*}{0.002} \\
\hline & $\hat{\mathrm{Q} 2}$ & $107(11.1)$ & $199(20.7)$ & $654(68.1)$ & \\
\hline 10. Being vaccinated myself has a positive influence on the & Q1 & $51(5.5)$ & $169(18.1)$ & $714(76.4)$ & \multirow{2}{*}{$p<0.001$} \\
\hline behaviour of my patients & Q2 & $29(3.0)$ & $81(8.4)$ & $850(88.5)$ & \\
\hline \multirow{2}{*}{$\begin{array}{l}\text { 11. Students should be vaccinated to reduce the transmission of } \\
\text { infectious diseases in hospitals }\end{array}$} & Q1 & $22(2.4)$ & $55(5.9)$ & $857(91.8)$ & \multirow{2}{*}{$p<0.001$} \\
\hline & $\widehat{\mathrm{Q}} 2$ & $11(1.1)$ & $26(2.7)$ & $923(96.1)$ & \\
\hline \multirow{2}{*}{$\begin{array}{l}\text { 12. I should review my vaccination status before starting clinical } \\
\text { training }\end{array}$} & Q1 & $28(3.0)$ & $112(12.0)$ & $794(85.0)$ & \multirow{2}{*}{0.132} \\
\hline & Q2 & $36(3.8)$ & $141(14.7)$ & $783(81.6)$ & \\
\hline \multirow{2}{*}{$\begin{array}{l}\text { 13. I should be vaccinated against influenza every year, even it } \\
\text { means missing hours of practical training }\end{array}$} & Q1 & $159(17.0)$ & $228(24.4)$ & $547(58.6)$ & \multirow{2}{*}{$p<0.001$} \\
\hline & Q2 & $95(9.9)$ & 187 (19.5) & 678 (70.6) & \\
\hline
\end{tabular}


Table 6. Cont.

\begin{tabular}{|c|c|c|c|c|c|}
\hline Questionnaire Items & SURVEY & $\begin{array}{l}\text { Disagree } \\
\text { n }(\%)\end{array}$ & $\begin{array}{l}\text { ND/NA } \\
\text { n (\%) }\end{array}$ & $\begin{array}{l}\text { Agreed } \\
\text { n (\%) }\end{array}$ & $p$ Value \\
\hline \multirow{2}{*}{ 14. I would be vaccinated irrespective of what my peers might do } & Q1 & $25(2.7)$ & $50(5.4)$ & $859(92.0)$ & \multirow{2}{*}{$p<0.001$} \\
\hline & $\widehat{\mathrm{Q}} 2$ & $15(1.6)$ & $20(2.1)$ & $925(96.4)$ & \\
\hline \multirow{2}{*}{ 15. If I am in good health there is no need to be vaccinated } & $\widehat{\mathrm{Q}} 1$ & $750(80.3)$ & $129(13.8)$ & $55(5.9)$ & \multirow{2}{*}{$p<0.001$} \\
\hline & Q2 & $866(90.2)$ & $52(5.4)$ & $42(4.4)$ & \\
\hline \multirow{2}{*}{$\begin{array}{l}\text { 16. I would recommend my patients adhere to the established } \\
\text { vaccination calendar }\end{array}$} & Q1 & $8(0.9)$ & $36(3.9)$ & $890(95.3)$ & \multirow[b]{2}{*}{0.002} \\
\hline & Q2 & $5(0.5)$ & $13(1.4)$ & $942(98.1)$ & \\
\hline \multirow{2}{*}{$\begin{array}{l}\text { 17. I would inform my patients of the effectiveness, indications and } \\
\text { side effects of each vaccine }\end{array}$} & Q1 & $6(0.6)$ & $29(3.1)$ & $899(96.3)$ & \multirow[b]{2}{*}{0.431} \\
\hline & $\mathrm{Q} 2$ & $5(0.5)$ & $21(2.2)$ & $934(97.3)$ & \\
\hline 18. I would travel to a tropical country only after consulting Spain's & Q1 & $35(3.7)$ & $51(5.5)$ & $848(90.8)$ & \multirow{2}{*}{0.428} \\
\hline International Vaccination about the vaccines I require & $\hat{\mathrm{Q} 2}$ & $40(4.2)$ & $65(6.8)$ & $855(89.1)$ & \\
\hline 19. I would be vaccinated against HIV when a vaccine becomes & Q1 & $32(3.4)$ & $74(7.9)$ & $828(88.7)$ & \multirow{2}{*}{0.762} \\
\hline available and when shown to be acceptably safe and effective & $\hat{\mathrm{Q} 2}$ & $28(2.9)$ & $72(7.5)$ & $860(89.6)$ & \\
\hline 20. If being vaccinated against influenza were readily accessible to & Q1 & $64(6.9)$ & $120(12.8)$ & $750(80.3)$ & \multirow{2}{*}{0.007} \\
\hline me, I would be vaccinated every year & $\hat{\mathrm{Q}} 2$ & $49(5.1)$ & $88(9.2)$ & $823(85.7)$ & \\
\hline \multirow{2}{*}{$\begin{array}{l}\text { 21. I would be vaccinated against anything my doctor recommends, } \\
\text { even if I have to pay for it }\end{array}$} & $\hat{\mathrm{Q}} 1$ & $87(9.3)$ & $261(27.9)$ & $586(62.7)$ & \multirow{2}{*}{0.545} \\
\hline & $\hat{\mathrm{Q} 2}$ & $101(10.5)$ & $252(26.3)$ & $607(63.2)$ & \\
\hline 22. When I begin work at a hospital, I will make sure I am & $\hat{\mathrm{Q}} 1$ & $10(1.1)$ & $56(6.0)$ & $868(92.9)$ & \multirow{2}{*}{0.022} \\
\hline vaccinated against everything preventable & $\widehat{\mathrm{Q}} 2$ & $10(1.0)$ & $32(3.3)$ & $918(95.6)$ & \\
\hline 23. I would only be vaccinated in exceptional circumstances & Q1 & $683(73.1)$ & $139(14.9)$ & $112(12.0)$ & \multirow{2}{*}{$p<0.001$} \\
\hline (epidemics, health alerts, etc. & Q2 & $826(86.0)$ & $89(9.3)$ & $45(4.7)$ & \\
\hline 24. I will be vaccinated against influenza every year I have & Q1 & $122(13.1)$ & $229(24.5)$ & $583(62.4)$ & \multirow{2}{*}{$p<0.001$} \\
\hline clinical training & Q2 & $61(6.4)$ & $175(18.2)$ & $724(75.4)$ & \\
\hline
\end{tabular}

Table 7 shows the results of the multivariate analysis, identifying the influencing independent variables and their effect size, for all three AVECS dimensions measured. Being a student of nursing was the variable that most positively influenced the scores for all three, followed by answering at the time of Q2. Being in the fourth (final) year of any degree was also associated with improvements in Beliefs and General Attitude, whereas the female sex was related to better Behaviour and General Attitude. Being in the third year of one's degree had a positive impact on beliefs.

Table 7. Multivariate analysis: relationships shown by the dimensions Beliefs, Behaviour and General Attitude with the variables sex, age, degree being pursued, and course year.

\begin{tabular}{|c|c|c|c|c|}
\hline Dependent Variable & Independent Variables & $\begin{array}{c}\text { Unstandardised Coefficients } \\
\text { B }(95 \% \mathrm{CI})\end{array}$ & Standardised Coefficients & $p$ Value \\
\hline \multirow{5}{*}{ Beliefs } & Constant & $2.938(2.868-3.008)$ & & $p<0.001$ \\
\hline & Nursing & $0.193(0.148-0.237)$ & 0.189 & $p<0.001$ \\
\hline & Survey: Q2 & $0.128(0.087-0.169)$ & 0.137 & $p<0.001$ \\
\hline & Course Year 4th & $0.103(0.051-0.155)$ & 0.091 & $p<0.001$ \\
\hline & Course Year 3rd & $0.069(0.019-0.120)$ & 0.063 & 0.007 \\
\hline \multirow{5}{*}{ Behaviour } & Constant & $3.059(2.975-3.144)$ & & $p<0.001$ \\
\hline & Nursing & $0.173(0.124-0.222)$ & 0.159 & $p<0.001$ \\
\hline & Q2 & $0.101(0.057-0.145)$ & 0.101 & $p<0.001$ \\
\hline & Female gender & $0.098(0.042-0.155)$ & 0.078 & 0.001 \\
\hline & Constant & $2.974(2.898-3.049)$ & & $p<0.001$ \\
\hline \multirow{4}{*}{ General attitude } & Nursing & $0.183(0.139-0.227)$ & 0.186 & $p<0.001$ \\
\hline & Q2 & $0.120(0.081-0.160)$ & 0.134 & $p<0.001$ \\
\hline & Course Year 4th & $0.067(0.019-0.115)$ & 0.061 & $p<0.001$ \\
\hline & Female gender & $0.058(0.007-0.108)$ & 0.050 & 0.026 \\
\hline
\end{tabular}

\section{Discussion}

This is the first work to compare attitudes towards vaccination among SHSs during the present pandemic. The results show that these were generally very positive to begin with, and that they improved during these difficult times. Some students, however, revealed some reticence in their answers to certain questions. For example, $10.1 \%$ were doubtful about the effectiveness of vaccination, and $14 \%$ questioned its cost-effectiveness. These results, which are similar to those reported by other authors who used the same questionnaire [26], could be conditioned by a poor perception of the risk posed by infectious disease to the young population $[27,28]$, or a lack of knowledge of vaccination in 
general and vaccination programs in particular $[11,12,17]$. The fact that the chiropody students do not undertake practical studies at health centres, and considering their-and physiotherapists' - lesser involvement in vaccination programs, might also have influenced the results $[19,29]$.

Previous studies have examined the change in attitude towards vaccination shown by the general population and health professionals. The Vaccine Confidence project reported that, between 2018 and 2020, public confidence in vaccines increased in most European countries, with the populations of Spain and Portugal the most confident of all [30]. In Spain, general confidence in vaccines grew from $64 \%$ to $70 \%$ (i.e., the percentage of respondents replying positively to [in agreement with] all items in the questionnaire used). The authors of that study point out that these findings could be influenced by people's perception of the seriousness of the pandemic. Other authors report a significant increase in general confidence in vaccination among the Italian population one year into the pandemic [31]. Similarly, vaccine hesitancy is reported to have diminished in Turkey [32] and Japan [33]. However, in the USA, there has been a general reduction in favourable attitudes towards vaccination over the course of the pandemic [34], with attitudes worsening among Republican voters but remaining stable among Democrat voters. Other studies, performed between March and August 2020, have shown growing reticence towards being vaccinated against COVID-19 among British and Irish populations [35].

With respect to healthcare personnel, Ledda et al. report attitudes to have improved among professionals at an Italian hospital over the course of the pandemic [36]. Della Polla et al. also report Italian workers (including healthcare workers) and students at the University of Naples to have shown a clear improvement in their attitude towards vaccination, and positive change towards employing general preventive measures against COVID-19, including the use of masks, washing hands and social distancing [37].

Several other studies report that the pandemic has changed the attitude of the general population [38], and of healthcare professionals, towards vaccination against influenza [39,40], perhaps due to an increased consciousness of airborne transmission [41].

In the present work, the factors that most influenced having a positive attitude were being a student of nursing, answering at the time of Q2, female gender and being in recent years of study.

The influence of being a student of nursing rather than another discipline (stronger even than the time of answering the questionnaire [Q1 or Q2]) may be explained by the fact that nurses are more involved and have greater responsibilities in vaccination programmes [29] and receive more information about, and training in, vaccination than the students of the other present degrees, and the correlation that exists between knowledge and attitude towards vaccination [11,15,42]. Other studies have reported the good disposition of students of nursing towards vaccination [26,42]. In fact, in a study performed in seven European countries, Spanish students of nursing showed the strongest disposition towards vaccination against COVID-19, followed by those studying in Italy [43].

After adjusting for age, sex and degree type, etc., answering at the time of Q2 was related to improvements in the measured dimensions, supporting the hypothesis that the pandemic has had a positive effect on attitude towards vaccination.

The students in their final years showed a better attitude towards vaccination, a phenomenon identified in earlier studies from Spain [26,42] and other countries [11,44-46]. This is probably related to the greater knowledge acquired and capacities developed by students further on in their studies. It should be noted that recent studies on vaccination against COVID-19 report the same [47,48]. In fact, non-health science students with greater knowledge of the COVID-19 vaccines are also reported to show better attitudes [14]. The strength of the relationship between deeper knowledge and acceptance of vaccination may be influenced by the effectiveness of information campaigns [14,30].

The better results seen for female students in the present work agree with previously reported studies [49-51]. It may be that women show greater solidarity [52], or that since 
male students of nursing are reduced in number, they may more often decline to take part in group activities that might influence their attitudes [53].

The good-and later, further improved-attitude towards vaccination seen in the present work is important since many studies concur that such attitudes improve the likelihood of requesting the influenza [54-57] and COVID-19 vaccines [43,48,58].

Finally, the present work has a number of limitations. The sample, although large, may not be entirely representative of SHSs at the national level; further studies at other universities are required to confirm the results. Moreover, the data used in analyses came from self-answered questionnaires, and such data can be affected by respondents' willingness to please.

\section{Conclusions}

The overall attitude of the present students towards vaccination was good, and improved significantly during the first 18 months of the pandemic, perhaps in part because of the education received and in part as a result of living through these times with their attendant fears and worries. The results show that attitudes can change for the better, reinforcing the need to promote health and increase the public's knowledge regarding vaccines and vaccination.

The fact that the COVID-19 vaccines can protect people from the worst of the disease, plus the information campaign surrounding vaccination against COVID-19, has probably improved people's perception of vaccination in general, making them more likely to accept vaccination against other diseases.

Further studies in other populations of health sciences students are required, both nationally and internationally. It will also be important to determine whether the improvements seen in this work are maintained after the pandemic has finally ended.

Author Contributions: Conceptualisation and methodology: F.J.P.-R. and R.D.G.-L.; validation, formal analysis and writing —original draft preparation: F.J.P.-R., C.M.A.M.-V., R.D.G.-L. and M.J.A.B.; research, writing-review: F.J.P.-R., R.D.G.-L., C.M.A.M.-V., M.J.A.B., C.L.-L., S.D.-F. and M.R.-B.; editing and visualisation: F.J.P.-R., R.D.G.-L., C.M.A.M.-V. and M.J.A.B. All authors have read and agreed to the published version of the manuscript.

Funding: This work was funded by the Universidad Complutense de Madrid via the 'Ayudas Económicas a los Grupos de Investigación UCM (Aplicación presupuestaria G/6400100/3000)'.

Institutional Review Board Statement: The study was conducted according to the guidelines of the Declaration of Helsinki, and approved by the Ethics in Research Committee of the Hospital Universitario Clínico San Carlos (protocol code 20/376-E and date of approval: 7 May 2021).

Informed Consent Statement: Informed consent was obtained from all subjects involved in the study. Written informed consent has been obtained from the patient(s) to publish this paper.

Data Availability Statement: Not applicable.

Acknowledgments: The authors thank the leaders of the nursing, physiotherapy and chiropody courses for allowing visits to classrooms, and all those students who took part.

Conflicts of Interest: The authors declare no conflict of interest.

\section{References}

1. Andre, E.; Booy, R.; Bock, H.L.; Clemens, J.; Datta, S.K.; John, T.J.; Lee, B.W.; Lolekha, S.; Peltola, H.; A Ruff, T.; et al. Vaccination greatly reduces disease, disability, death and inequity worldwide. Bull. World Health Organ. 2008, 86, 140-146. [CrossRef]

2. Dubé, E.; Vivion, M.; MacDonald, E.N. Vaccine hesitancy, vaccine refusal and the anti-vaccine movement: Influence, impact and implications. Expert Rev. Vaccines 2015, 14, 99-117. [CrossRef] [PubMed]

3. Larson, S.; de Figueiredo, A.; Karafillakis, E.; Rawal, M. The State of Vaccine Confidence in the EU 2018. Luxemburg: London School of Hygiene and Tropical Medicine, 2018. Available online: https://ec.europa.eu/health/sites/health/files/vaccination/ docs/2018_vaccine_confidence_en.pdf (accessed on 2 December 2021). 
4. European Centre for Disease Prevention and Control. Vaccine Hesitancy among Healthcare Workers and Their Patients in Europe-A Qualitative Study; ECDC: Stockholm, Sweden, 2015. Available online: https://www.ecdc.europa.eu/sites/default/files/media / en/publications/Publications/vaccine-hesitancy-among-healthcare-workers.pdf (accessed on 2 December 2021).

5. Karafillakis, E.; Dinca, I.; Apfel, F.; Cecconi, S.; Wúrz, A.; Takacs, J.; Suk, J.; Celentano, L.P.; Kramarz, P.; Larson, H.J. Vaccine hesitancy among healthcare workers in Europe: A qualitative study. Vaccine 2016, 34, 5013-5020. [CrossRef] [PubMed]

6. Yaqub, O.; Castle-Clarke, S.; Sevdalis, N.; Chataway, J. Attitudes to vaccination: A critical review. Soc. Sci. Med. 2014, 112, 1-11. [CrossRef] [PubMed]

7. Paterson, P.; Meurice, F.; Stanberry, L.R.; Glismann, S.; Rosenthal, S.L.; Larson, H.J. Vaccine hesitancy and healthcare providers Vaccine 2016, 34, 6700-6706. [CrossRef] [PubMed]

8. Dubé, E. Addressing vaccine hesitancy: The crucial role of healthcare providers. Clin. Microbiol. Infect. 2017, 23, 279-280. [CrossRef] [PubMed]

9. Herzog, R.; Álvarez-Pasquin, M.J.; Díaz, C.; Del Barrio, J.L.; Estrada, J.M.; Gil, Á. Are healthcare workers' intentions to vaccinate related to their knowledge, beliefs and attitudes? A systematic review. BMC Public Health 2013, 13, 154. [CrossRef]

10. Mergler, M.J.; Omer, S.B.; Pan, W.K.; Navar-Boggan, A.M.; Orenstein, W.; Marcuse, E.K.; Taylor, J.; Dehart, M.P.; Carter, T.C.; Damico, A.; et al. Association of vaccine-related attitudes and beliefs between parents and health care providers. Vaccine 2013, 31, 4591-4595. [CrossRef]

11. Cvjetkovic, S.J.; Jeremic, V.L.; Tiosavljevic, D.V. Knowledge and attitudes toward vaccination: A survey of Serbian students. J. Infect. Public Health 2017, 10, 649-656. [CrossRef]

12. Berera, D.; Thompson, K.M. Medical Student Knowledge, Attitudes, and Practices Regarding Immunization. J. Vaccines Vaccin. 2012, 6, 2. [CrossRef]

13. Walker, L.; Newall, A.; Heywood, A.E. Knowledge, attitudes and practices of Australian medical students towards influenza vaccination. Vaccine 2016, 34, 6193-6199. [CrossRef] [PubMed]

14. Gallè, F.; Sabella, E.A.; Roma, P.; De Giglio, O.; Caggiano, G.; Tafuri, S.; Da Molin, G.; Ferracuti, S.; Montagna, M.T.; Liguori, G.; et al. Knowledge and Acceptance of COVID-19 Vaccination among Undergraduate Students from Central and Southern Italy. Vaccines 2021, 9, 638. [CrossRef] [PubMed]

15. Dybsand, L.L.; Hall, K.J.; Carson, P.J. Immunization attitudes, opinions, and knowledge of healthcare professional students at two Midwestern universities in the United States. BMC Med. Educ. 2019, 19, 1-9. [CrossRef] [PubMed]

16. Lehmann, A.B.; Ruiter, R.A.C.; Wicker, S.; Chapman, G.; Kok, G. Medical students' attitude towards influenza vaccination. BMC Infect. Dis. 2015, 15, 1-7. [CrossRef]

17. Pelly, L.P.; MacDougall, D.M.P.; A Halperin, B.; Strang, A.R.; Bowles, S.K.; Baxendale, D.M.; McNeil, A.S. The Vaxed Project: An Assessment of Immunization Education in Canadian Health Professional Programs. BMC Med. Educ. 2010, 10, 86. [CrossRef]

18. La Fauci, V.; Squeri, R.; Genovese, C.; Anzalone, C.; Fedele, F.; Squeri, A.; Alessi, V. An observational study of university students of healthcare area: Knowledge, attitudes and behaviour towards vaccinations. Clin Ter. 2019, 170, e448-e453. [CrossRef]

19. Pérez-Rivas, F.J.; Del Gallego-Lastra, R.; Esteban-Garcimartín, A.; Marques-Vieira, C.M.A.; Ajejas-Bazán, M.J. Attitude towards Vaccination among Health Science Students before the COVID-19 Pandemic. Vaccines 2021, 9, 644. [CrossRef]

20. European Centre for Disease Prevention and Control. Rapid Risk Assessment: Outbreak of Novel Coronavirus Disease 2019 (COVID19.): Increased Transmission Globally; ECDC: Stockholm, Sweden, 2020. Available online: https://www.ecdc.europa.eu/sites/ default/files / documents / RRA-outbreak-novel-coronavirus-disease-2019-increase-transmission-globally-COVID-19.pdf (accessed on 2 December 2021).

21. Cuello, J.M.A. La pandemia de la COVID-19 como debate público: El caso español. Anu. Electrónico Estud. Comun. Social Disert. 2021, 14, 2. [CrossRef]

22. Pal, S.; Shekhar, R.; Kottewar, S.; Upadhyay, S.; Singh, M.; Pathak, D.; Kapuria, D.; Barrett, E.; Sheikh, A.B. COVID-19 Vaccine Hesitancy and Attitude toward Booster Doses among US Healthcare Workers. Vaccines 2021, 9, 1358. [CrossRef]

23. Mingarro, F.A.I.; Castellanos Claramunt, J.C. COVID-19, fake news and vaccination: The need to immunize society from vaccine hesitancy. Cuad. Bioética Rev. Of. Asoc. Española Bioética Ética Médica 2021, 32, 63-73. [CrossRef]

24. Pullan, S.; Dey, M. Vaccine hesitancy and anti-vaccination in the time of COVID-19: A Google Trends analysis. Vaccine 2021, 39, 1877-1881. [CrossRef] [PubMed]

25. Hotez, P. COVID-19 and the rise of anti-science. Expert Rev. Vaccines 2021, 20, 227-229. [CrossRef] [PubMed]

26. Fernández-Prada, M.; Ramos-Martín, P.; Madroñal-Menéndez, J.; Martínez-Ortega, C.; González-Cabrera, J. Diseño y validación de un cuestionario sobre vacunación en estudiantes de ciencias de la salud. Rev. Esp. Salud. Publica 2016, 7, e1-e10.

27. Agüero Santagelo, F.; Nebot Adell, M.; Pérez Giménez, A.A.; López Medina, M.J.; García Continente, X. Attitudes and preventive behaviours adopted during the (H1N1) 2009 influenza virus epidemic in Spain. Rev. Esp. Salud Publica 2011, 85, 73-80. [CrossRef]

28. Saura, S.; Jorquera, V.; Mascort, C.; Castellà, I. Gender meanings of the risk of sexually transmitted infections/HIV transmission among young people. Aten. Primaria 2020, 52, 218-219. [CrossRef]

29. Forcada, J.A. El acto vacunal. Vacunas 2014, 15, 272-283. [CrossRef]

30. Figueiredo, A.; Karafillakis, E. Vaccine Confidence Project. State of Vaccine Confidence in the EU+UK. A Report for the European Commission; European Union, 2020: Luxemburgo. Available online: https://ec.europa.eu/health/sites/default/files/ vaccination/docs/2020_confidence_rep_en.pdf (accessed on 7 December 2021). 
31. Domnich, A.; Grassi, R.; Fallani, E.; Spurio, A.; Bruzzone, B.; Panatto, D.; Marozzi, B.; Cambiaggi, M.; Vasco, A.; Orsi, A.; et al. Changes in Attitudes and Beliefs Concerning Vaccination and Influenza Vaccines between the First and Second COVID-19 Pandemic Waves: A Longitudinal Study. Vaccines 2021, 9, 1016. [CrossRef]

32. Yılmazbaş, P.; Terzi, Ö.; Özçeker, D. Did COVID-19 Pandemic Changed Parents' Approach to Vaccination? Erciyes Med. J. 2021, 43, 130-134. [CrossRef]

33. Harada, T.; Watanabe, T. Changes in Vaccine Hesitancy in Japan across Five Months during the COVID-19 Pandemic and Its Related Factors. Vaccines 2022, 10, 25. [CrossRef]

34. Fridman, A.; Gershon, R.; Gneezy, A. COVID-19 and vaccine hesitancy: A longitudinal study. PLoS ONE 2021, 16, e0250123. [CrossRef]

35. Hyland, P.; Vallières, F.; Shevlin, M.; Bentall, R.P.; McKay, R.; Hartman, T.K.; McBride, O.; Murphy, J. Resistance to COVID-19 vaccination has increased in Ireland and the United Kingdom during the pandemic. Public Health 2021, 195, 54-56. [CrossRef] [PubMed]

36. Ledda, C.; Costantino, C.; Cuccia, M.; Maltezou, C.C.; Rapisarda, V. Attitudes of Healthcare Personnel towards Vaccinations before and during the COVID-19 Pandemic. Int. J. Environ. Res. Public Health 2021, 18, 2703. [CrossRef]

37. Della Polla, G.; Pelullo, C.P.; Di Giuseppe, G.; Angelillo, I.F. Changes in Behaviors and Attitudes in Response to COVID-19 Pandemic and Vaccination in Healthcare Workers and University Students in Italy. Vaccines 2021, 9, 1276. [CrossRef] [PubMed]

38. Bachtiger, P.; Adamson, A.; Chow, J.J.; Sisodia, R.; Quint, J.K.; Peters, N.S. The Impact of the COVID-19 Pandemic on the Uptake of Influenza Vaccine: UK-Wide Observational Study. JMIR Public Health Surveill. 2021, 7, e26734. [CrossRef]

39. Bertoni, L.; Roncadori, A.; Gentili, N.; Danesi, V.; Massa, I.; Nanni, O.; Altini, M.; Gabutti, G.; Montella, M.T. How has COVID-19 pandemic changed flu vaccination attitudes among an Italian cancer center healthcare workers? Hum. Vaccines Immunother. 2021, 1-6. [CrossRef] [PubMed]

40. Stöckeler, A.M.; Schuster, P.; Zimmermann, M.; Hanses, F. Influenza vaccination coverage among emergency department personnel is associated with perception of vaccination and side effects, vaccination availability on site and the COVID-19 pandemic. PLoS ONE 2021, 16, e0260213. [CrossRef] [PubMed]

41. Wang, K.; Wong, E.; Ho, K.F.; Cheung, A.; Chan, E.; Yeoh, E.K.; Wong, S. Intention of nurses to accept coronavirus disease 2019 vaccination and change of intention to accept seasonal influenza vaccination during the coronavirus disease 2019 pandemic: A cross-sectional survey. Vaccine 2020, 38, 7049-7056. [CrossRef]

42. Tuells, J.; Egoavil, C.M.; Morales-Moreno, I.; Fortes-Montoya, E.; Salazar-García, C.; Rodríguez-Blanco, N. Knowledge, Attitudes, and Sources of Information on Vaccines in Spanish Nursing Students: A Cross-Sectional Study. Int. J. Environ. Res. Public Health 2021, 18, 3356. [CrossRef]

43. Patelarou, E.; Galanis, P.; Mechili, E.A.; Argyriadi, A.; Argyriadis, A.; Asimakopoulou, E.; Brokaj, S.; Bucaj, J.; Carmona-Torres, J.M.; Cobo-Cuenca, A.I.; et al. Factors influencing nursing students' intention to accept COVID-19 vaccination: A pooled analysis of seven European countries. Nurse Educ. Today 2021, 104, 105010. [CrossRef]

44. Mjrby, L.M.; Sahli, A.A.; Alsrori, Z.M.; Kamili, F.H.; Althurwi, H.A.; Zalah, A.A.; Alharbi, H.M.; Alharbi, H.M. Knowledge and attitudes toward vaccination among Saudi medical students. J. Fam. Med. Prim. Care 2020, 9, 2079-2084. [CrossRef]

45. Rostkowska, O.M.; Peters, A.; Montvidas, J.; Magdas, T.M.; Rensen, L.; Zgliczyński, W.S.; Durlik, M.; Pelzer, B.W. Attitudes and Knowledge of European Medical Students and Early Graduates about Vaccination and Self-Reported Vaccination CoverageMultinational Cross-Sectional Survey. Int. J. Environ. Res. Public Health 2021, 18, 3595. [CrossRef] [PubMed]

46. Szmyd, B.; Bartoszek, A.; Karuga, F.F.; Staniecka, K.; Błaszczyk, M.; Radek, M. Medical Students and SARS-CoV-2 Vaccination: Attitude and Behaviors. Vaccines 2021, 9, 128. [CrossRef]

47. Sovicova, M.; Zibolenova, J.; Svihrova, V.; Hudeckova, H. Odds Ratio Estimation of Medical Students' Attitudes towards COVID-19 Vaccination. Int. J. Environ. Res. Public Health 2021, 18, 6815. [CrossRef] [PubMed]

48. Sugawara, N.; Yasui-Furukori, N.; Fukushima, A.; Shimoda, K. Attitudes of Medical Students toward COVID-19 Vaccination: Who Is Willing to Receive a Third Dose of the Vaccine? Vaccines 2021, 9, 1295. [CrossRef] [PubMed]

49. Zarobkiewicz, M.K.; Zimecka, A.; Zuzak, T.; Cieślak, D.; Roliński, J.; Grywalska, E. Vaccination among Polish university students. Knowledge, beliefs and anti-vaccination attitudes. Hum. Vaccines Immunother. 2017, 13, 2654-2658. [CrossRef] [PubMed]

50. Villanueva, S.; Mosteiro-Miguéns, D.G.; Domínguez-Martís, E.M.; López-Ares, D.; Novío, S. Knowledge, Attitudes, and Intentions towards Human Papillomavirus Vaccination among Nursing Students in Spain. Int. J. Environ. Res. Public Health 2019, 16, 4507. [CrossRef]

51. Chen, G.; Wu, B.; Dai, X.; Zhang, M.; Liu, Y.; Huang, H.; Mei, K.; Wu, Z. Gender Differences in Knowledge and Attitude towards HPV and HPV Vaccine among College Students in Wenzhou, China. Vaccines 2022, 10, 10. [CrossRef]

52. Christensen, M.; Welch, A.; Barr, J. Men are from Mars: The challenges of communicating as a male nursing student. Nurse Educ. Pract. 2018, 33, 102-106. [CrossRef]

53. Jiang, N.; Wei, B.; Lin, H.; Wang, Y.; Chai, S.; Liu, W. Nursing students' attitudes, knowledge and willingness of to receive the coronavirus disease vaccine: A cross-sectional study. Nurse Educ. Pract. 2021, 55, 103148. [CrossRef]

54. Rogers, C.J.; Bahr, K.O.; Benjamin, S.M. Attitudes and barriers associated with seasonal influenza vaccination uptake among public health students; a cross-sectional study. BMC Public Health 2018, 18, 1131. [CrossRef]

55. Cornally, N.; Deasy, E.A.; McCarthey, G.; McAuley, C.; Moran, J.; Weathers, E. Student nurses' intention to get the influenza vaccine. Br. J. Nurs. 2013, 22, 1207-1211. [CrossRef] [PubMed] 
56. Cheung, K.; Ho, S.M.S.; Lam, W. Factors affecting the willingness of nursing students to receive annual seasonal influenza vaccination: A large-scale cross-sectional study. Vaccine 2017, 35, 1482-1487. [CrossRef] [PubMed]

57. Lee, D.; Rundle-Thiele, S.; Li, G. Motivating Seasonal Influenza Vaccination and Cross-Promoting COVID-19 Vaccination: An Audience Segmentation Study among University Students. Vaccines 2021, 9, 1397. [CrossRef] [PubMed]

58. Zhou, Y.; Wang, Y.; Li, Z. Intention to get vaccinated against COVID-19 among nursing students: A cross-sectional survey. Nurse Educ. Today 2021, 107, 105152. [CrossRef] 